\title{
„Regularny wypoczynek tygodniowy, obejmujący przynajmniej niedzielę" - ocena gwarancji prawnych w perspektywie Laborem exercens
}

\section{Praca jako źródło uprawnień pracowniczych}

„Praca nosi na sobie szczególne znamię człowieka i człowieczeństwa”. Słowa te stanowią swoiste motto encykliki Laborem exercens ${ }^{1}$. Wskazując na pracę jako źródło utrzymania oraz rozwoju społecznego, Papież Jan Paweł Il zaznaczył, że człowiek wykonuje pracę „w pocie czoła, to znaczy nie tylko przy osobistym wysiłku i trudzie, ale także wśród wielu napięć, konfliktów i kryzysów" (LE 1). Sprzeciwiając się traktowaniu jej jako sui generis towaru (LE 7), zaakcentował godność pracy, przez którą człowiek „urzeczywistnia siebie jako człowiek, a także poniekąd bardziej «staje się człowiekiem»” (LE 9). Zasada pierwszeństwa „pracy” przed „kapitałem” (LE 12) zakłada gwarancje uprawnień pracowniczych („praw ludzkich wynikających z pracy”), rozpatrywanych „w szerokim kontekście ogółu praw właściwych człowiekowi” (LE 16).

" Dr Marcin A. Mielczarek, Katedra Prawa Pracy, Wydział Prawa i Administracji, Uniwersytet Łódzki, 90-232 Łódź, ul. Kopcińskiego 8/12.

1 Jan PAwEk II, Encyklika „Laborem exercens”, [w:] idem, Dzieła zebrane, t. 1: Encykliki, Kraków 2006, s. 107-143. Dalej jako LE. 


\section{Wypoczynek tygodniowy w katolickiej nauce społecznej}

Do uprawnień ludzi pracy Papież zaliczył w szczególności prawo do wypoczynku, zwłaszcza „regularnego wypoczynku tygodniowego, obejmującego przynajmniej niedzielę" (LE 19). Nawiązał w ten sposób do postulatów sformułowanych uprzednio w encyklikach Rerum novarum Leona XIII ${ }^{2}$ oraz Mater et Magistra Jana XXIII' , kładąc nacisk na względy socjalne, wyrażone w przywołanych dokumentach granicami sprawności ludzkiej (RN, cz. II, 2) oraz troską o zdrowie fizyczne i psychiczne (MeM, cz. IV, 4b). Doniosłość papieskiego postulatu wyraża się w jego utrwaleniu w Magisterium Ecclesiae oraz włączeniu do treści opracowanego przez Papieską Radę „lustitia et Pax" Kompendium nauki społecznej Kościoła („Świąteczny odpoczynek jest prawem”).

Uzasadniając przytoczone stanowisko, Jan Paweł II nie pominął argumentu stricte religijnego, silnie eksponowanego przez jego poprzedników. Zmienione warunki geopolityczne, szczególnie odejście od modelu państwa wyznaniowego, nie pozwalały już na kategoryczne i bezpośrednie wymaganie od władz cywilnych przestrzegania - w poczuciu „odpowiedzialności wobec Boga i społeczeństwa” - przykazania odpoczynku świątecznego, tzn. „przerwy w pracy, uświęconej wpływem religii" (MeM, cz. IV, 4b; RN, cz. II, 2). Zasadnicze uznanie przez Kościół katolicki laickości państwa, pojmowanej jako autonomia sfery obywatelskiej i politycznej w stosunku do sfery religijnej i kościelnej (z wyłączeniem sfery moralności $)^{5}$, nie oznacza braku możliwości uzasadnienia w inny sposób obowiązku władz publicznych (w stosunku do obywateli) oraz pracodawców (względem pracowników) zapewnienia czasu wolnego przeznaczonego na odpoczynek i kult religijny ${ }^{6}$. Encyklika Laborem exercens nie wskazuje wyraźnie tego nowego typu argumentacji, jakkolwiek zawiera się on w postulacie niedzieli jako minimalnego wymiaru odpoczynku tygodniowego. Uwidacznia się on w Katechizmie Kościoła Katolickiego w nawiązaniu do wolności religijnej (KKK 2188). Zagwarantowanie prawa do obchodzenia świąt religijnych jako przejawu wolności religijnej można i należy rozpatrywać w kategorii obowiązku władz publicznych, a jego realizacja nie stoi w sprzeczności z zasadą neutralności światopoglądowej państwa i nie świadczy o jego konfesjonalizacji .

${ }^{2}$ Leon XIII, Encyklika „Rerum novarum”, [w:] Encykliki społeczne Kościoła Katolickiego, Świdnica 2005, s. 9-43. Dalej jako RN.

3 Jan XXIII, Encyklika „Mater et Magistra”, [w:] Encykliki społeczne Kościoła Katolickiego, s. 47117. Dalej jako MeM.

${ }^{4}$ Papieska Rada „Iustitia et Pax”, Kompendium nauki społecznej Kościoła, nr 284, Kielce 2005.

${ }^{5}$ Kongregacja Nauki Wiary, Nota doktrynalna o niektórych aspektach działalności i postępowania katolików w życiu politycznym, nr 5, „L'Osservatore Romano” 2003, nr 2, s. 49-54.

${ }^{6}$ Katechizm Kościoła Katolickiego, wyd. 2. popr., Poznań 2002, nr 2187. Dalej jako KKK.

7 A. Dyıus, Czy przegraliśmy niedzielę? O sensie świętowania, „Chrześcijaństwo - Świat - Polityka" 2007, nr 3, s. 15-16. 
Tezy encykliki dotyczące odpoczynku tygodniowego stały się ponownie przedmiotem nauczania Jana Pawła II w liście apostolskim Dies Domini z jednoczesnym rozwinięciem kwestii ich podstaw, tzn. ludzkiej godności oraz związanych z nią potrzeb religijnych, rodzinnych, kulturowych i społecznych, trudnych do zaspokojenia, ,jeśli nie jest zagwarantowany przynajmniej jeden dzień w tygodniu dający wszystkim możliwość wspólnego odpoczynku i świętowania" (DD 66-67). Papieska wizja odpoczynku świątecznego jako kulminacji czasu wolnego wynikała z połączenia w teologicznej refleksji czasu wolnego z celebracją niedzieli jako Dnia Pańskiego ${ }^{9}$. „Dla chrześcijan nie jest to sytuacja normalna” - argumentował - „gdy niedziela, dzień święta i radości, nie jest także dniem odpoczynku, a w każdym razie trudno im «świętować» niedzielę, jeśli nie dysponują odpowiednią ilością wolnego czasu" (DD 64).

\section{3. Świętowanie niedzieli jako źródło wypoczynku tygodniowego}

Wiążąc minimalny wymiar odpoczynku tygodniowego z niedzielą, Papież dokonał interpretacji prawa do wypoczynku na poziomie prawa do wolności religijnej i implicite sprzeciwił się sekularyzacji niedzieli, sprowadzającej jej obchodzenie do kulturowej tradycji10. Nadmienić należy, że o ile w konwencjach nr 14 i $106 \mathrm{MOP}^{11}$ oraz w Europejskiej Karcie Społecznej ${ }^{12}$ aspekt religijny odpoczynku tygodniowego został dostrzeżony przez odwołanie do tradycji lub zwyczaju danego kraju lub regionu, o tyle w prawie Unii Europejskiej - wskutek orzeczenia ETS z 1996 r. w sprawie United Kingdom of Great Britain and Northern Ireland $v$ Council of the European Union (Case C-84/94) $)^{13}$ - uchylono akapit drugi art. 5 dyrektywy 93/104/WE w sprawie niektórych aspektów organizacji czasu pracy ${ }^{14}$, zgodnie z którym minimalny, nieprzerwany 24-godzinny odpoczynek tygodniowy zasadniczo powinien obejmować niedzielę. Rozstrzygnięcie ETS znalazło swoje odzwierciedlenie w dyrektywie nowelizującej 2000/34/WE ${ }^{15}$ oraz w obowiązującej dyrektywie 2003/88/WE ${ }^{16}$.

8 Jan PaWek II, List apostolski „Dies Domini” o świętowaniu niedzieli, [w:] idem, Dzieła zebrane, t. 3: Listy, Kraków 2007, s. 450-487. Dalej jako DD.

9 M. Ostrowskı, Czas wolny, [w:] Encyklopedia nauczania społecznego Jana Pawła II, red. A. Zwoliński, Radom 2003, s. 88.

10 Zob. szerzej: A. Wóscık, Prawo obywatela-katolika do niedzielnego odpoczynku, „Annales Canonici" 2007, nr 3, s. 67-86.

11 Dz.U. 1925, nr54, poz.384, http://www.mop.pl/doc/html/konwencje/k106.html[dostęp: 16.10.2013].

12 Dz. U. 1999, nr 8, poz. 67.

13 L. FLoReK, Czas pracy i urlopy wypoczynkowe w prawie europejskim, „Praca i Zabezpieczenie Społeczne" 1999, nr 2, s. 13; idem, Europejskie prawo pracy, Warszawa 2010, s. 163.

14 Dz. Urz. UE Wydanie specjalne z 2004 r., rozdz. 05/t. 2, s. 197.

15 Dz. Urz. UE Wydanie specjalne z 2004 r., rozdz. 05/t. 4, s. 27.

16 Dz.Urz. UE Wydanie specjalne z 2004 r., rozdz. 05/t. 4, s. 381. 
Stanowisko Jana Pawła II wiąże się z faktem, że niedziela, będąca - cytując za soborową konstytucją Sacrosanctum Concilium - „pierwotnym dniem świątecznym”, „podstawą i rdzeniem roku liturgicznego”17, stanowiła początkowo jedyne święto chrześcijańskie. Charakter paschalny jako wyłączny rys chrześcijańskiej heortologii został zachowany do IV w. ${ }^{18}$, przy czym doroczne świętowanie Wielkanocy, które przyjęło wówczas w pełni rozwiniętą postać Triduum Paschalnego i okresu Pięćdziesiątnicy ${ }^{19}$, datuje się - na podstawie dostępnych źródeł historycznych - na początek II w. ${ }^{20}$ Fundamentalne znaczenie niedzieli w cyklu tygodniowym dla zdecydowanej większości Kościołów chrześcijańskich odpowiada znaczeniu Wielkanocy w roku liturgicznym ${ }^{21}$. Ranga niedzieli bierze swój początek z wydarzenia paschalnego, co dało asumpt do sformułowania tezy, że „Wielkanoc jest jedynie uwypukloną niedzielą"22. Paschalny charakter niedzieli odzwierciedla zwłaszcza rosyjska nazwa воскресенье (zmartwychwstanie); polskie określenie „niedziela” (pochodzące najprawdopodobniej od połączenia partykuły „nie” i czasownika „działać”) zwraca uwagę na - znacznie później sformalizowany - obowiązek powstrzymania się od pracy ${ }^{23}$.

Jak podkreśla się w piśmiennictwie teologicznym, brak jest wiarygodnych dowodów pozwalających na upatrywanie w świętowaniu niedzieli zjawiska chrystianizacji przez Kościół rzymski pogańskiego „dnia słońca” jako przejawu kultów solarnych ${ }^{24}$. Świętowanie niedzieli nie wynika z arbitralnej decyzji Kościoła, ale stanowi rezultat sprawowania w tym dniu Eucharystii jako anamnezy (uobecnienia) wydarzenia Zmartwychwstania Pańskiego ${ }^{25}$. Z kolei określenie celebracji eucharystycznej mianem Wieczerzy Pańskiej (1 Kor 11, 20) miało wywrzeć wpływ na traktowanie jako synonimicznych pojęć „niedziela” i „Dzień Pański”, skutkiem czego zwrot (dies) dominica stał się nazwą własną niedzieli w języku łacińskim, obecną do dzisiaj w zmienionych formach w językach romańskich (np. wł. domenica, fr. dimanche) ${ }^{26}$. Przejście od szabatu do niedzieli (jako wyraz przejścia od Starego do Nowego Przymierza) nie jest - zdaniem J. Ratzingera - równoznaczne z dualistyczną interpretacją świętych dni judaizmu i chrześcijaństwa jako przeciwstawnych rzeczywistości - „niedziela w sposób naturalny włącza w siebie treść szabatu”: będąc dniem trzecim (po śmierci Jezusa) - jest

17 Konstytucja „Sacrosanctum Concilium” o liturgii świętej, nr 106, [w:] Sobór Watykański II. Konstytucje, dekrety, deklaracje, Poznań 2002. Dalej jako KL.

18 B. Nadolski, Liturgika, t. 2: Liturgia i czas, Poznań 1991, s. 91-92.

19 A. Bergamini, Chrystus - świętem Kościoła, Kraków 2004, s. 56.

20 B. NAdolski, Liturgika, t. 2, s. 55.

21 J. Czerski, Dzień święty w Starym i Nowym Testamencie, [w:] Niedziela w społeczeństwie pluralistycznym, red. E. Mateja, R. Pierskała, Opole 2001, s. 31.

22 M. Kunzler, Liturgia Kościoła, Poznań 1999, s. 615.

23 B. NAdolski, Liturgika, t. 2, s. 35.

24 E. Bianchi, Niedziela. Dzień Pana, dzień człowieka, Poznań 1998, s. 122.

25 J. Klinger, Geneza sporu o epiklezę, Warszawa 1969, s. 30.

26 M. KunZler, op. cit., s. 618. 
(w świetle teologii judaistycznej) dniem teofanii, będąc pierwszym dniem tygodnia (jom riszon) - obejmuje pamiątkę początku kreacji świata, a jako dzień ósmy - nabiera wymiaru eschatologicznego ${ }^{27}$.

Istnieje zatem nierozerwalny związek między świętowaniem niedzieli jako "cotygodniowej paschy" a początkiem istnienia chrześcijaństwa ${ }^{28}$. Zakorzeniona w Dekalogu teologia święta jako dnia wypoczynku nie stanowiła prymarnej motywacji świętowania niedzieli ${ }^{29}$. Zastrzeżenie obowiązku świątecznego pod rygorem grzechu ciężkiego, silnie akcentowanym w okresie kontrreformacji, datuje się na połowę XV w..$^{30}$, a ta swoista „zmiana akcentu” mogła nastąpić dzięki ustanowieniu niedzieli dniem wolnym od pracy przez cesarza Konstantyna Wielkiego ${ }^{31}$.

Wymowę niedzieli uwypukliła posoborowa reforma liturgiczna, stanowiąc w Ogólnych normach roku liturgicznego $i$ kalendarza ${ }^{32}$, że liturgiczny obchód niedzieli ustępuje tylko uroczystościom oraz świętom Pańskim, z zastrzeżeniem bezwzględnego pierwszeństwa niedziel Adwentu, Wielkiego Postu i Okresu Wielkanocnego (ONRLK 5). Tym samym uwidoczniono charakter niedzieli jako „podstawy i rdzenia roku liturgicznego", której nie powinny przesłaniać inne obchody, jeżeli nie są rzeczywiście bardzo ważne (KL 106). W okresie poprzedzającym reformę liturgii rzymskiej, na gruncie Codex Rubricarum z 1960 r., wyróżniano niedziele I i II klasy33; do pierwszej kategorii należało jednak tylko 13 spośród 52-53 niedziel występujących w roku liturgicznym ${ }^{34}$, co wiązało się z ryzykiem zaciemnienia bądź utraty paschalnego wymiaru niedzieli, zwłaszcza w związku z rozwojem Sanctorale ${ }^{35}$.

Według konstytucji Sacrosanctum Concilium, ranga niedzieli implikuje w szczególności obowiązek duchowieństwa podejmowania odpowiednich działań, aby w świadomości i pobożności wiernych dzień ten „stał się również dniem radości i odpoczynku od pracy" (KL 106). W dodatku do tejże konstytucji Sobór Watykański II nie sprzeciwił się idei stałego kalendarza świeckiego pod warunkiem zachowania podziału na siedmiodniowe tygodnie. Podział ten nie jest bowiem „przypadkową okolicznością historyczną, do której Kościół nie przywiązuje wagi i z której mógłby zrezygnować" (DD 64) - wzorem francuskiego kalendarza rewolucyjnego z décades zamiast tygodni i décadi jako cyklicznym dniem wolnym od pracy ${ }^{36}$. Znamienne jest, że konstrukcja tego kalendarza wyraźnie

27 J. Ratzinger, Duch liturgii, [w:] idem, Opera omnia, t. 11: Teologia liturgii, Lublin 2012, s. 84-86.

${ }_{28}$ B. NAdolski, Niedziela. Historia, znaczenie, symbolika, Kraków 2010, s. 44.

29 Ibidem.

${ }^{30}$ M. KUNZLER, op. cit., s. 624.

${ }^{31}$ E. BIANCHI, op. cit., s. 19, 170 i n.

32 Ogólne normy roku liturgicznego i kalendarza, [w:] Mszał rzymski dla diecezji polskich, Poznań 1986, s. [66]-[74]. Dalej jako ONRLK.

${ }^{33}$ Codex Rubricarum - Rubricae generales, 10, [w:] Missale Romanum ex decreto Ss. Concilii Tridentini restitutum, Summorum Pontificum cura recognitum. Editio typica, Romae 1962.

${ }^{34}$ Codex Rubricarum - Rubricae generales, 11.

35 M. KUNZLER, op. cit., s. 625.

36 N. Davies, Europa. Rozprawa historyka z historią, Kraków 1999, s. 746. 
wskazuje na ideę likwidacji tygodni - rozpoczynających się od niedzieli - jako miary czasu, przy jednoczesnych rzekomych gwarancjach „wolności przekonań, także religijnych", sformułowanych w art. X Deklaracji Praw Człowieka i Obywatela z 26 sierpnia 1789 r. Koncepcja 12 miesięcy (od vendémiaire’a do fructidora), liczących po trzy dziesięciodniowe décades, stała bowiem w sprzeczności z długością roku solarnego, co wymagało dodawania - poza porządkiem miesięcznym - 5 dni zwanych sans-culottides oraz - w czwartym roku każdej franciade - dnia „przestępnego” (Jour de la Révolution) ${ }^{37}$. Zaznaczyć wypada, że kalendarz gregoriański powrócił do powszechnego użytku dopiero w okresie Konsulatu ${ }^{38}$, co nie pozwala - w świetle badań przeprowadzonych przez R. Sechera - obarczyć odpowiedzialnością za nieprzestrzeganie praw człowieka wyłącznie jakobinów39.

Warto odnotować fakt podjęcia przez Sobór Watykański II dyskusji na temat reformy kalendarza gregoriańskiego. Przedłożony projekt dostrzegał wady istniejącego kalendarza, w którym liczba dni w roku nie odpowiada pełnym tygodniom, przez co brak jest m.in. powiązania określonych dni miesiąca (w tym terminów świąt stałych) $z$ dniami tygodnia. W celu eliminacji (wymienionych tu jedynie przykładowo) mankamentów zakładał podział roku na 13 miesięcy po 28 dni (4 tygodnie) każdy. Kwestia pozostałego 365 . dnia roku $(13 \times 28=364)$ miałaby być rozwiązana przez usytuowanie go (jako dnia 14. bis siódmego miesiąca pacificus, wprowadzonego pomiędzy czerwcem i lipcem) poza numeracją tygodniową (jako tzw. długą niedzielę) $)^{40}$. Nastąpiłoby jednak w ten sposób zakłócenie biegu dni tygodnia, co w świetle cytowanego stanowiska Soboru, dopuszczającego reformę kalendarza przy utrzymaniu siedmiodniowych tygodni, przesądziło - jak można domniemywać - o odrzuceniu projektu.

\section{Wypoczynek tygodniowy jako uprawnienie pracownicze - ocena regulacji prawnych}

Kiedy Papież składał podpis pod tekstem encykliki Laborem exercens, zwracając uwagę na niemożność jej ogłoszenia w dziewięćdziesiątą rocznicę Rerum novarum ze względu na związaną z zamachem hospitalizację, w Polsce mijał ponad rok od zawarcia Porozumień Sierpniowych. Zasadnicze źródło prawa pracowników do wypoczynku stanowiły wówczas - obowiązujące do dzisiaj w zmienionych wersjach - ustawa z 18 stycznia 1951 r. o dniach wolnych od pracy ${ }^{41}$ oraz Kodeks pracy ${ }^{42}$.

37 Ibidem, s. 747.

38 Ibidem.

39 R. SECHER, Ludobójstwo francusko-francuskie. Wandea Departament Zemsty, Warszawa 2003, s. 171-172, 178, 199.

40 Kalendarze, red. E. Gigilewicz, Lublin 2003, s. 52-54.

41 Dz. U. 1951, nr 4, poz. 28, ze zm.

${ }^{42}$ Tekst pierwotny: Dz. U. 1974, nr 24, poz. 141; tekst obowiązujący: t. jedn. Dz. U. 1998, nr 21, poz. 94, ze zm. 
W ówczesnym przepisie art. 138 (obecnie art. $151^{9}$ ) Kodeks pracy przyznawał status dni wolnych od pracy niedzielom oraz świętom, nie wymieniając ich z nazwy, ale odsyłając do odrębnych przepisów. Nie określał jednak minimalnego wymiaru odpoczynku tygodniowego. Dwudziesty pierwszy postulat z 17 sierpnia 1980 r. („Wprowadzić wszystkie soboty wolne od pracy”) ${ }^{43}$ był powoli i specyficznie realizowany przez ustawodawcę: początkowo - w wyniku noweli lutowej z 1996 r. ${ }^{44}$ - przez instytucję dodatkowych dni wolnych od pracy, a następnie od 2001 r. ${ }^{45}$ - przez de facto przeciętnie pięciodniowy tydzień pracy. Dopiero nowelizacja Kodeksu pracy z 2003 r. ${ }^{46}$, mająca na celu dostosowanie polskiego prawa pracy do standardów Unii Europejskiej, przyznała pracownikom prawo do co najmniej 35 godzin nieprzerwanego odpoczynku tygodniowego (art. $133 \S 1$ k.p.), który zasadniczo powinien przypadać w niedzielę (art. $133 \S 3$ k.p.).

Kodeks pracy odróżnia niedziele jako dni wolne od pracy od świąt (w tym świąt religijnych). Czynił to już w brzmieniu obowiązującym przed 1 stycznia 2004 r., różnicując obowiązki pracodawcy w zależności od tego, czy świadczenie pracy przez pracownika miało miejsce w niedzielę czy w święto. Obecnie zbieg święta z niedzielą oznacza - na podstawie art. $151^{11} \S 4$ k.p. - utratę statusu święta i obowiązek stosowania przepisów Kodeksu pracy dotyczących pracy w niedzielę. Odstępstwo od wskazanej regulacji przewiduje dodany w 2007 r. ${ }^{47}$ art. $151^{9 a}$ k.p., wprowadzający zakaz pracy w placówkach handlowych w święta (ust. 1), także wówczas, gdy przypadają one w niedzielę (ust. 2). Jakkolwiek przepis ten stanowi swego rodzaju cząstkową odpowiedź na wątpliwości co do sposobu redakcji art. $151^{10}$ k.p. (o czym mowa poniżej), może - niestety - służyć jednocześnie za przykład złej legislacji. Dość zauważyć, że art. 1519a k.p. jest jedynym przepisem Kodeksu pracy podzielonym na ustępy, a także wyjątkiem od określonego unormowania, usytuowanym w tekście prawnym przed nim samym (tzn. art. $151^{10}$ k.p.).

Wagę pominięcia przez ustawodawcę wymiaru religijnego niedzieli wzmacnia regulacja przepisów art. $151^{11}$ i $151^{12}$ k.p. Nie sposób nie dostrzec, że „status niedzieli i święta jako dnia wolnego od pracy jest znacznie słabiej chroniony niż tzw. wolnej soboty”, skoro ustawodawca „dopuszcza możliwość nieoddania niedzieli w naturze"48. Ponadto, o ile w przypadku pracy w niedzielę rekompensata w postaci dnia wolnego powinna nastąpić do końca okresu rozliczeniowego, gdyby

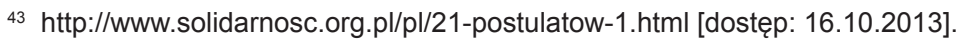

44 Dz. U. 1996, nr 24, poz. 110. W wyniku nowelizacji wprowadzono przepis art. $129^{1}$ k.p., w tym $\S 1$ w brzmieniu: „Przy wprowadzaniu rozkładów czasu pracy, o którym mowa w art. 129, uwzględnia się 39 dodatkowych dni wolnych od pracy w roku kalendarzowym, przy czym w każdym okresie obejmującym kolejne trzy miesiące liczba tych dni nie może być mniejsza niż 9".

45 Dz. U. 2001, nr 28, poz. 301.

46 Dz. U. 2003, nr 213, poz. 2081.

47 Dz. U. 2007, nr 176, poz. 1239.

48 A. SoвczYк, Kilka uwag na tle nowelizacji czasu pracy, „Praca i Zabezpieczenie Społeczne” 2003, nr 12, s. 24. 
okazała się niemożliwa w pierwotnym terminie (art. $151^{11} \S 2$ k.p.), o tyle brak możliwości udzielenia dnia wolnego w zamian za pracę w święto nie wiąże się z odsunięciem w czasie realizacji obowiązku pracodawcy, ale ze zmianą formy rekompensaty (art. $151^{11} \S 3$ k.p.). Na krytyczną ocenę zasługuje również liberalizacja przepisów dotyczących pracowników pracujących w niedzielę (z wyjątkiem zatrudnionych w tzw. systemie pracy weekendowej), którym przysługuje niedziela wolna od pracy raz na 4 tygodnie (art. $151^{12}$ k.p.), a nie, jak do końca 2003 r. - raz na 3 tygodnie, co niewątpliwie wywiera wpływ na zakres realizacji prawa do wolności religijnej i - w pewnym zakresie (np. w kontekście relacji rodzinnych) prawa do wypoczynku. Dostrzec jednocześnie trzeba ryzyko błędnej wykładni tego przepisu, polegającej na dzieleniu okresu rozliczeniowego na czterotygodniowe okresy, w których dowolnie można by wyznaczyć niedzielę wolną od pracy, co mogłoby skutkować wykonywaniem pracy przez więcej niż 3 kolejne niedziele ${ }^{49}$. Przywołać należy tu ponownie papieski postulat regularności wypoczynku, choć w analizowanym przypadku interwał między niedzielami wolnymi od pracy będzie dłuższy niż tydzień.

W nowelizacji z 2003 r. rozwiązano tylko częściowo problemy związane z pojęciem dnia wolnego od pracy. W poprzednim stanie prawnym wskazywano w doktrynie, że jako niedzielę wolną od pracy powinno się traktować 24 kolejne godziny wolne, obliczone w sposób przewidziany w ówczesnym art. 138 § 2 k.p. ${ }^{50}$ Sąd Najwyższy w uchwale składu 7 sędziów z 26 czerwca 1981 r. (V PZP 5/81) zaznaczył, że „godziny wolne od pracy” są odwróceniem uregulowanego w art. 138 § 2 k.p. pojęcia „pracy w niedzielę”, a zatem są zdefiniowane za pomocą zasady wyrażonej w tym przepisie ${ }^{51}$. Z kolei w uchwale składu 7 sędziów z 10 lutego 1994 r. (I PZP 49/93) zauważył, że sposób rozumienia dnia wolnego od pracy „nie może być oderwany od pojęcia dnia pracy i dnia pracy w niedzielę" 52 . Zapatrywania SN znalazły odzwierciedlenie w treści art. $133 \S 3$ k.p., zgodnie z którym niedziela - jako dzień odpoczynku tygodniowego - obejmuje 24 kolejne godziny, poczynając od godziny 6.00 w tym dniu, chyba że u danego pracodawcy została ustalona inna godzina. Oczywiste jest zastosowanie tej definicji do sytuacji uregulowanej w art. $151^{12}$ k.p. Na pytanie o możliwość odniesienia jej do równoważnego dnia wolnego od pracy ustawodawca nie udziela odpowiedzi. Państwowa Inspekcja Pracy w tym przypadku skłania się ku wykładni łączącej początek dnia wolnego od pracy z zakończeniem doby pracowniczej ${ }^{53}$.

49 E. SzemplińSKA, Konsultacje i wyjaśnienia, „Praca i Zabezpieczenie Społeczne” 2005, nr 12, s. 38.

50 J. SzCZERSKI, Glosa do uchwały SN z 26 czerwca 1981 r., V PZP 5/81, „Praca i Zabezpieczenie Społeczne" 1983, nr 2, s. 59.

51 OSNC 1981, nr 10, poz. 181.

52 OSNA PIUS 1994, nr 8, poz. 123.

53 Zob. J. StęPNIAK, Zdaniem Państwowej Inspekcji Pracy, „Praca i Zabezpieczenie Społeczne” 2009, nr 3, s. 41. 
Wprawdzie motywy ochrony niedzieli jako dnia wolnego od pracy mogą być różnorodne w zależności od wartości leżących u ich podstaw (np. indywidualnych lub społecznych ${ }^{54}$ ), pierwszorzędne znaczenie - obok prawa pracowników do dni wolnych od pracy, wyrażonego w art. 66 ust. 2 Konstytucji RP ${ }^{55}$, powinien mieć związek z zagwarantowaną w art. 53 ustawy zasadniczej wolnością sumienia i religii. Zróżnicowanie statusu niedzieli i świąt rzutuje na ocenę zakresu dozwolonej pracy w niedziele i święta. Niedostrzeganie teologicznego i liturgicznego aspektu niedzieli oznacza bowiem brak refleksji ustawodawcy na temat dopuszczalności pracy w niedziele i święta z perspektywy konstytucyjnych wymogów ograniczeń wolności uzewnętrzniania religii. Przepis art. 53 ust. 5 Konstytucji, podobnie jak art. 31 ust. 3, przewiduje, że ograniczenia te muszą być konieczne w demokratycznym państwie prawnym, m.in. dla ochrony zdrowia lub praw i wolności innych osób, co wskazuje na ich wyjątkowy charakter. Trybunał Konstytucyjny w uzasadnieniu wyroku z 16 lutego 1999 r. (SK 11/98) przyjął, że przepis art. 53 ust. 5 „nie wyłącza zastosowania zasady proporcjonalności wyrażonej w art. 31 ust. 3"56, tzn. zakazu naruszania istoty konstytucyjnych wolności i praw.

Tymczasem w wyniku noweli lutowej użyte w pkt 10 ówczesnego art. 139 k.p. pojęcie prac koniecznych ze względu na ich użyteczność społeczną i codzienne potrzeby ludności nie zostało ani zdefiniowane, ani zastąpione bardziej precyzyjnym sformułowaniem, a ich przykładowy (sic!) katalog poszerzono o pracę w placówkach handlowych oraz pracę w zakładach świadczących usługi dla ludności. Ustawodawca uznał zatem, ignorując konieczność istnienia relacji między pojęciem zbiorczym a poszczególnymi sytuacjami nim objętymi, że zawieranie umów kupna-sprzedaży bez względu na przedmiot transakcji oraz świadczenie jakichkolwiek usług stanowi przesłankę uzasadniającą pracę w niedziele i święta - tym samym ograniczenie prawa do dni wolnych od pracy oraz prawa do wolności religijnej.

Nowelizację Kodeksu pracy z 2003 r. cechowała dalsza liberalizacja przepisów dotyczących zakresu dopuszczalności pracy w niedziele i święta. Jako okoliczność wymagającą świadczenia przez pracownika pracy w dni ustawowo wolne od pracy ustawodawca wskazał m.in. pracę zmianową (art. $151^{10}$ pkt 3 k.p.), tzn. wykonywanie pracy według ustalonego rozkładu czasu pracy przewidującego zmianę pory wykonywania pracy przez poszczególnych pracowników po upływie określonej liczby godzin, dni lub tygodni (art. $128 \S 2$ k.p.). Jak dowodzi się w doktrynie, praca zmianowa stanowi „relatywnie liberalną przesłankę dopuszczalności pracy w niedziele i święta”, przede wszystkim z uwagi na jej nieprecyzyjną definicję. Nie wynika z niej bowiem, że „dotyczy ona pracowników, którzy

54 A. Dytus, Niedziela w epoce globalizacji gospodarki, „Liturgia Sacra” 2001, nr 1, s. 18-19; eadem, Kapitał społeczny świąt religijnych, „Annales. Etyka w życiu gospodarczym” 2007, nr 1, s. 200-204.

55 Dz. U. 1997, nr 78, poz. 483, ze zm.

56 OTK 1999, nr 2, poz. 22. 
zmieniają się przy wykonywaniu określonej pracy", co umożliwia objęcie pojęciem pracy zmianowej przypadku „zatrudniania pracownika, któremu pracodawca wyznaczy różne godziny rozpoczęcia pracy (lub pory jej rozpoczęcia) w poszczególnych tygodniach" ${ }^{57}$. Ponadto dostrzega się, że przepis art. $151^{10}$ k.p. nie przewiduje wymagania stosowania pracy zmianowej w systemie całodobowym, zatem może to być również praca dwuzmianowa ${ }^{58}$. Poza tym wykonywanie pracy przez pracowników zatrudnionych przy pracy zmianowej (bądź w innych przypadkach pracy dopuszczalnej w niedziele i święta z powodu zastosowanej organizacji pracy) może wymagać obecności pracowników niezmianowych, np. przełożonych tych pracowników ${ }^{59}$.

Kolejne zmiany art. $151^{10}$ k.p. nastąpiły w latach 2011 i 2014. Po pierwsze, na mocy ustawy z 9 czerwca 2011 r. o wspieraniu rodziny i systemie pieczy zastępczej60 pojęcie „placówek opiekuńczo-wychowawczych” (pkt 9 lit. g) zastąpiono od 1 stycznia 2012 r. sformułowaniem ,jednostki organizacyjne wspierania rodziny i systemu pieczy zastępczej". Po drugie, ustawą z 24 stycznia 2014 r. o zmianie ustawy - Kodeks pracy ${ }^{61}$ do przepisu art. $151^{10} \mathrm{k}$.p. dodano punkt 11 , dopuszczający pracę $w$ niedziele i święta przy wykonywaniu prac polegających na świadczeniu usług z wykorzystaniem środków komunikacji elektronicznej w rozumieniu przepisów o świadczeniu usług drogą elektroniczną lub urządzeń telekomunikacyjnych $w$ rozumieniu przepisów prawa telekomunikacyjnego, odbieranych poza terytorium Rzeczypospolitej Polskiej, jeżeli zgodnie z przepisami obowiązującymi odbiorcę usługi, dni, o których mowa w art. $151^{9} \S 1$ k.p., są u niego dniami pracy (lit. a) oraz prac zapewniających możliwość świadczenia tychże usług (lit. b). O ile nie da się zaprzeczyć, że współcześnie gospodarki krajowe stanowią system naczyń połączonych, o tyle trudno zrozumieć de facto wyłączenie stosowania ustawy o dniach wolnych od pracy w stosunku do pracowników świadczących w określony sposób pracę na rzecz podmiotów zagranicznych tylko ze względu na odmienne katalogi dni wolnych od pracy w obcych systemach prawnych. Ustawodawca nie wskazał bowiem okoliczności mających uzasadniać pierwszeństwo innego porządku prawnego przed regulacją polską. Wątpliwości budzi także jednostronność wprowadzonej zmiany, na którą należałoby spojrzeć z innej perspektywy, gdyby - z zachowaniem zasady wzajemności - wynikała $z$ umowy multilateralnej.

W perspektywie obowiązującej Konstytucji redakcję art. $151^{10} \mathrm{k} . p$. trzeba ocenić krytycznie, nie tylko ze względu na wprowadzenie nowych i utrzymanie istniejących już w brzmieniu przepisu zwrotów niedookreślonych. Na dezaprobatę

\footnotetext{
57 A. SoBczYk, Kilka uwag..., s. 21.

${ }^{58}$ K. RaczKa, Komentarz do art. $151^{10}$ k.p., [w:] M. Gersdorf, K. RaczKa, J. Skoczyński, Kodeks pracy. Komentarz, red. Z. Salwa, Warszawa 2008, s. 614.

59 A. Sовсzүк, Zasady prawnej regulacji czasu pracy, Warszawa 2005, s. 240.

60 Dz. U. 2011, nr 149, poz. 887, ze zm.

61 Dz. U. 2014, poz. 208.
} 
zasługuje jeszcze bardziej zachowanie przez ustawodawcę katalogu otwartego ${ }^{62}$ przesłanek dozwolonej pracy w niedziele i święta, który ewidentnie koliduje z krańcową koniecznością i wyjątkowym charakterem ograniczeń konstytucyjnych praw i wolności. Świadczy to o zaniedbaniach prawodawcy w dostosowywaniu do wymogów Konstytucji uprzednich w stosunku do niej regulacji prawnych, zawartych w ustawodawstwie zwykłym ${ }^{63}$.

Dla uzyskania pełnego obrazu unormowań dotyczących dni wolnych od pracy nie sposób nie przypomnieć prób zwiększenia wymiaru czasu pracy kosztem prawa do odpoczynku. W latach 2004-2006 w sytuacji, gdy w tygodniu występowały dwa święta w inne dni niż niedziela, obniżenie wymiaru czasu pracy na podstawie art. $130 \S 2$ k.p. następowało tylko z tytułu jednego dnia świątecznego. Implikowało to konieczność odpracowywania jednego ze świąt ${ }^{64}$, co - w myśl poglądu przytoczonego w uzasadnieniu wyroku TK z 30 czerwca 2009 r. (K 14/07) - było „sprzeczne z istotą dnia świątecznego"65, zagwarantowanego w art. 66 ust. 2 Konstytucji RP. W literaturze prawniczej trafnie zaznaczono, że „nie można mówić o dniach wolnych od pracy, jeśli pracownik de facto nie zostaje zwolniony z obowiązku pracy, a jedynie obowiązek ten zostaje przełożony na inny dzień"66. Ryzyko odpracowywania dnia wolnego od pracy stało się znów realne w latach 2011-2012 wskutek wprowadzenia nowelizacją z 24 września 2010 r. $^{67}$ - jako swego rodzaju „rekompensaty” ustanowienia tzw. święta Trzech Króli dniem wolnym od pracy - przepisu art. $130 \S 2^{1}$ k.p., który umożliwiał części pracodawców manipulowanie terminem dnia wolnego od pracy wynikającego z przeciętnie pięciodniowego tygodnia pracy w celu zwiększenia nominału czasu pracy ${ }^{68}$. Na mocy wyroku Trybunału Konstytucyjnego z 2 października 2012 r. (K 27/11) ${ }^{69}$ art. $130 \S 2^{1}$ k.p. utracił moc obowiązującą ze względu na sprzeczność $z$ art. 32 ust. 1 Konstytucji RP.

Obok negatywnych aspektów aktualnej regulacji czasu pracy w niedziele i święta wypada zwrócić uwagę na pewne pozytywne zmiany dokonane przez ustawodawcę na gruncie Kodeksu pracy. Specjalnego podkreślenia wymaga przede wszystkim określenie w art. 133 k.p. wymiaru odpoczynku dobowego

62 A. M. ŚwiąTKowski, Kodeks pracy. Komentarz, Warszawa 2012, s. 756; K. StefańSKI, Problem pracy w dni świąteczne, „Praca i Zabezpieczenie Społeczne” 2007, nr 12, s. 20.

${ }^{63}$ M. A. Mielczarek, Realizacja wolności religijnej w zatrudnieniu pracowniczym, Warszawa 2013, s. 244.

64 M. NAŁĘCZ, Zbieg dwu dni świątecznych w jednym tygodniu, „Monitor Prawa Pracy” 2006, nr 4, s. $196-198$.

65 OTK-A 2009, nr 6, poz. 87.

${ }^{66}$ K. STEFAŃSkI, Konieczność odpracowania dni wolnych - uwagi dotyczące art. 130 § 2 k.p., „Praca i Zabezpieczenie Społeczne” 2006, nr 4, s. 17.

67 Dz. U. 2010, nr 224, poz. 1459.

${ }^{68}$ Zob. K. RĄczkA, Święto Trzech Króli, „Praca i Zabezpieczenie Społeczne” 2010, nr 10, s. 2 okładki; K. Stefański, Problem świąt przypadających $w$ dni wolne od pracy wynikające z pięciodniowego tygodnia pracy, „Praca i Zabezpieczenie Społeczne” 2010, nr 12, s. 17-18.

${ }_{69}$ Dz. U. 2012, poz. 1110; OTK-A 2012, nr 9, poz. 102. 
i tygodniowego. Poza tym z aprobatą powinno zostać przyjęte objęcie obowiązkiem rekompensaty nie tylko pracy w niedzielę, ale i pracy w święto (do końca 2003 r. w myśl dawnego art. 140 k.p. nie była ona obligatoryjna) oraz uregulowanie terminów udzielenia pracownikowi dnia wolnego od pracy, co wcześniej wywoływało rozbieżności interpretacyjne ${ }^{70}$. Zgodnie $z$ art. $151^{11} \S 1$ k.p., w brzmieniu ustawy obowiązującym od 1 stycznia 2004 r., pracownikowi wykonującemu pracę w niedziele i święta, z wyjątkiem systemu pracy weekendowej (art. 144 k.p.), pracodawca jest obowiązany zapewnić inny dzień wolny od pracy: w zamian za pracę w niedzielę - w okresie 6 dni kalendarzowych poprzedzających lub następujących po takiej niedzieli, zaś za pracę w święto - w ciągu okresu rozliczeniowego. Istotne jest także, że pracodawca ma obowiązek zapewnienia pracownikowi całego dnia wolnego w zamian za pracę w niedzielę lub święto, niezależnie od czasu realnie przepracowanego ${ }^{71}$, co już w pierwszych latach obowiązywania Kodeksu pracy znalazło potwierdzenie w uchwale Sądu Najwyższego z 4 czerwca 1982 r. (III PZP 17/82) ${ }^{72}$.

\section{Aksjologiczne podstawy prawnej ochrony niedzieli jako dnia wolnego od pracy}

Przeświadczenie o pierwszeństwie „pracy” przed „kapitałem” - prymacie człowieka wobec rzeczy (LE, nr 12) - wiąże się z genezą prawa pracy, które stanowiło reakcję na dziewiętnastowieczny kapitalizm i patologię ówczesnych stosunków zatrudnienia, bazujących na „przywróconej do życia” w nowych uwarunkowaniach rzymskiej konstrukcji prawnej locatio conductio operarum i związanej z nią kwalifikacji pracy ludzkiej jako towaru, podlegającego rynkowej „grze” popytu i podaży ${ }^{73}$. Wynika stąd jako zasadnicza dla tej gałęzi prawa funkcja ochronna, a świadomość roli, jaką ma do spełnienia prawo pracy, wymaga od prawodawcy wszechstronnej oceny sytuacji pracowników - również z punktu widzenia aksjologii.

Przepisy dotyczące pracy w niedziele i święta (zwłaszcza art. $151^{10}$ k.p.) nie realizują tej funkcji w sposób kompleksowy. Potwierdza to przypadkowość niektórych rozwiązań prawnych i świadczy o błędnym rozumieniu dynamiki prawa pracy, tzn. nie jako właściwej odpowiedzi na ewolucję warunków społeczno-gospodarczych przy zachowaniu fundamentalnych założeń, ale jako - destrukcyjne niekiedy dla jego spójnego kształtu - otwarcie na konkurujące ze sobą wartości oraz stojące za nimi doktryny i koncepcje ekonomiczne, polityczne i filozoficzne.

70 Por. K. RączKa, Dni wolne od pracy, „Praca i Zabezpieczenie Społeczne” 2001, nr 8, s. 26; P. WoJciechowski, Zdaniem Państwowej Inspekcji Pracy, „Praca i Zabezpieczenie Społeczne” 2002, nr 7, s. 38; E. SZEMPLIŃSKA, op. cit., s. 39.

71 K. RACZKa, Dni wolne..., s. 26.

72 OSNC 1982, nr 10, poz. 148.

${ }^{73}$ F. ZoLl, Prawo pracy w biegu wieków, Wilno 1930, passim. 
Argument ekonomiczny, jakkolwiek istotny, nie może przeważać nad prawem pracowników do wypoczynku oraz związanym z nim aspektem religijnym; w przeciwnym razie należałoby konsekwentnie stwierdzić, że „Polski nie stać” na dni wolne od pracy i - wykraczające poza ogólnikowe deklaracje konstytucyjne - gwarancje wolności religii. Stanowisko o drugorzędności maksymalizacji zysków względem praw pracowniczych znajduje uzasadnienie w antropologii filozoficznej Jana Pawła II, w której „fundamentalne znaczenie ma zagadnienie podmiotowości osoby ludzkiej”74. W encyklice Laborem exercens czytamy: „Pierwszą podstawą wartości pracy jest sam człowiek - jej podmiot. Wiąże się z tym od razu bardzo ważny wniosek natury etycznej: o ile prawdą jest, że człowiek jest przeznaczony i powołany do pracy, to jednak nade wszystko praca jest «dla człowieka», a nie człowiek «dla pracy»” (LE 6). Pracę zaś, będącą „dobrem «godziwym», czyli odpowiadającym godności człowieka, wyrażającym tę godność i pomnażającym ją” (LE 9), należy mierzyć „miarą godności samego podmiotu pracy, czyli osoby: człowieka, który ją spełnia” (LE 6).

Wraz ze zmianami kulturowymi i cywilizacyjnymi, które doskonale ilustruje ewolucja stosunków przemysłowych w XIX w., a zwłaszcza gwałtowny współcześnie rozwój technologiczny, cykl dni pracy oraz dni przeznaczonych na odpoczynek i świętowanie zatracił pierwotną klarowność. W sensie ścisłym zaprzestanie wszelkiej pracy w niedziele i święta nie jest już możliwe. Kwestią otwartą pozostaje natomiast delimitacja między pracą niezbędnie konieczną w dni świąteczne a pracą użyteczną ze względu na oczekiwania pracodawców i społeczne zwyczaje.

Nie można nie wspomnieć, że zakaz pracy w niedziele i pozostałe święta nakazane nie miał nigdy charakteru bezwzględnego. Przykładowo, w świetle wyników badań mediewistów, w Polsce średniowiecznej handel w święta był dozwolony, ale dopiero po zakończeniu głównej mszy (sumy), nie zaś podczas trwania ceremonii religijnych, a wyjątek od zakazu publicznego handlu w dni świąteczne dotyczył tylko podstawowych artykułów żywnościowych nabywanych dla bieżącej konsumpcji lub towarów niezbędnych osobom podróżującym ${ }^{75}$. Również w Katechizmie Kościoła Katolickiego zwraca się uwagę, że „obowiązki rodzinne lub ważny pożytek społeczny stanowią słuszne usprawiedliwienie niewypełniania nakazu odpoczynku niedzielnego", odwołując się do zdania z dzieła św. Augustyna De civitate Dei: „Umiłowanie prawdy szuka czasu wolnego, a potrzeba miłości podejmuje uzasadnioną pracę" (KKK 2185).

Notabene, wpływ zmian społeczno-gospodarczych na zjawisko świętowania czy (szerzej) czasu wolnego odnotowywano już na przełomie lat 60. i 70.

74 Z. Grocholewski, Filozofia prawa w nauczaniu Jana Pawła II, [w:] idem, Refleksje na temat prawa, Kraków 2009, s. 63.

75 I. SkIERSKA, Handel w dzień święty w Polsce średniowiecznej, [w:] Przestrzeń religijna Europy Środkowo-Wschodniej w średniowieczu, red. K. Bracha, P. Kras, Warszawa 2010, s. 59-61. Zob. szerzej: I. SkIERskA, Sabbatha sanctifices. Dzień święty w średniowiecznej Polsce, Warszawa 2008, s. $235-460$. 
ubiegłego wieku, wskazując na zasadniczą różnicę między społeczeństwami tradycyjnymi (zwłaszcza społeczeństwami kultury agrarnej) a społeczeństwami industrialnymi. O ile bowiem „w społeczeństwie tradycyjnym nie istnieje wyraźne rozgraniczenie między czasem pracy zawodowej a czasem wolnym od pracy, ponieważ w miejscu zamieszkania wspólnoty rodzinne j dokonuje się praca produkcyjna i w tym samym miejscu lub w najbliższym jego sąsiedztwie ludzie odpoczywają”, o tyle w społeczeństwie przemysłowym „zachodzi konieczność

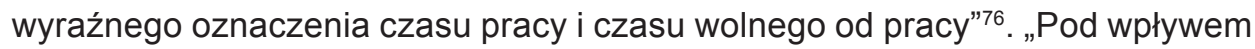
stosowanych na coraz szerszą skalę form organizacji produkcji przemysłowej [...] człowiek [...] spychany jest do roli dodatku do maszyny"77. Pogląd ten, sformułowany w latach 80. XX w., nabiera szczególnej wagi w kontekście rozwoju technologicznego ostatnich dekad oraz transformacji ustroju gospodarczego i potwierdza potrzebę gwarancji prawa do odpoczynku w sposób uwzględniający na poziomie minimum jego aspekt religijny. Brak wyeksponowania w regulacjach dotyczących czasu pracy tej relacji można wytłumaczyć socjalistyczną proweniencją obowiązującego Kodeksu pracy. Dla porównania, warto zauważyć, że Kodeks zobowiązań z $1933 \mathrm{r}^{78}$, dostrzegając przenikanie się sfery świadczenia usług i sfery sacrum, zobowiązywał pracodawcę do zapewnienia pracownikowi, przyjętemu w poczet domowników, odpowiedniego czasu na odpoczynek i praktyki religijne (art. 464 k.z.). Analogiczny obowiązek ciążył - zgodnie $z$ art. $477 \S 2$ k.z. - na pracodawcy zatrudniającym ucznia na podstawie umowy o naukę.

Konieczność wykonywania określonego rodzaju prac w dni świąteczne prowadzi w konsekwencji do uszczuplenia indywidualnej wolności religijnej oraz wymaga innego trybu realizacji przez pracowników prawa do odpoczynku tygodniowego. Wobec tego obowiązkiem ustawodawcy jest prawna ochrona dni świątecznych w taki sposób, aby sytuacje skutkujące ograniczeniami wolności religijnej i prawa do wypoczynku zostały zredukowane do niezbędnego minimum. Posługując się zwrotem zaczerpniętym z biblijnego Listu św. Jakuba, można powiedzieć, że jest on zobligowany „wprowadzać słowo w czyn” (Jk 1, 22) - konkretyzując ogólne normy konstytucyjne w taki sposób, aby posiadały one autentyczną wartość, w przeciwieństwie do podobnych im aktów historycznych, np. wspomnianej Deklaracji Praw Człowieka i Obywatela. W innym przypadku wolności osobiste i prawa socjalne wyrażone w Konstytucji miałyby wyłącznie charakter postulatywny, co stawiałoby pod znakiem zapytania ratio legis ich włączenia do tekstu ustawy zasadniczej.

76 J. SIEG, Problemy cywilizacji wolnego czasu, „Śląskie Studia Historyczno-Teologiczne” 1970, T. III, s. 95-96.

77 Z. GAkDzıCKI, Humanizacja pracy ludzkiej w encyklice, [w:] Laborem exercens. Powołany do pracy - Komentarz pod redakcją ks. Jana Kruciny, Wrocław 1983, s. 274.

78 Dz. U. 1933, nr 82, poz. 598, ze zm. 


\section{Podsumowanie}

„Z papieskiego nauczania przebija głęboka nadzieja, że przedmiotowy i podmiotowy wymiar pracy będzie prowadzić do rozwijania w każdym pracowniku człowieczeństwa przez właściwe układanie stosunków między zatrudnianym a pracodawcą bezpośrednim, w warunkach stwarzanych przez pracodawcę pośredniego”79. Według Jana Pawła II, porządek prawny „powinien szanować i popierać godność osoby ludzkiej, jej fundamentalną podmiotowość, jej wymiar integralny, jej dobro, jej niezbywalne prawa”; „powinno to być przede wszystkim rozumiane w legislacji dotyczącej ludzkiej pracy" ${ }^{\prime \prime 0}$. Kompatybilność polskich regulacji dotyczących w ogólności czasu pracy, a w szczególności prawa do odpoczynku tygodniowego, z wartościami przywoływanymi w nauczaniu społecznym Jana Pawła II wymaga nie tylko każdorazowej analizy konstytucyjności projektowanych rozwiązań prawnych, lecz także głębszej refleksji na temat granic liberalizacji prawa pracy.

Dziesięć lat po publikacji encykliki Laborem exercens, w encyklice Centesimus annus Papież Jan Paweł II sformułował pytanie: „Czy obowiązujące systemy prawne, a także praktyka panująca w społeczeństwach uprzemysłowionych skutecznie zapewniają dzisiaj korzystanie z podstawowego prawa do odpoczynku świątecznego"81? Wobec dynamiki rozwoju stosunków społeczno-ekonomicznych pozostaje ono stale aktualne.

79 F. Longchamps de Bérier, Jan Paweł Il o prawie do pracy i zabezpieczenia społecznego. W pierwszą rocznicę śmierci, „Praca i Zabezpieczenie Społeczne” 2006, nr 4, s. 6.

80 Z. GROCHOLEWSKI, op. cit., s. 94.

81 Jan Pawet II, Encyklika „Centesimus annus”, nr 9 [w:] idem, Dzieła zebrane, t. 1: Encykliki, Kraków 2006, s. 399-445. 